\title{
In-Service Language Teachers' Perceptions on the National Bilingualism Program Implementation: A Case Study*
}

\author{
ALBERTO FAJARDO CASTAÑEDA** \\ IVÁN RICARDO MIRANDA M."
}

Forma de citar este artículo: Fajardo, A. \& Miranda, I. R. (2018). In-Service Language Teachers' Perceptions on the National Bilingualism Program Implementation: A Case Study. Cuadernos de Lingüística Hispánica, (32), 195-215.

* Artículo producto de la investigación "Percepciones de los docentes de lenguas frente a la implementación del Programa Nacional de Bilingüismo", y el proyecto generado se denomina "Análisis crítico del discurso en la política educativa de bilingüismo españolinglés".

** Ph.D. in Education and Applied Linguistics; M.A. in applied Linguistics to EFL Teaching; Associated Teacher at Universidad Pedagógica y Tecnológica de Colombia. E-mail: albertofajardocas@hotmail.com

*** M.A. in English Applied Linguistics; M.A. in Applied Linguistics to EFL Teaching, Doctor in Language and Culture candidate; Associated Teacher at Universidad Pedagógica y Tecnológica de Colombia. E-mail: ivan.miranda@uptc.edu.co 


\section{Abstract}

This paper reports on the insights of a case study carried out between 2012 and 2013 within the Municipality of Sogamoso, Boyacá state, Colombia. The study mainly sought the perceptions of in-service language teachers regarding the establishment of a national bilingual model in their local educational system. Furthermore, the project intended to contrast the policy adopted by the Ministry of Education of Colombia with what the language teachers think the implementation of the National Bilingualism Program should be. Under the principles of qualitative research, and by using a questionnaire and a group interview as data-collecting instruments, findings reveal a conspicuous tension between what it is proposed by the government and what is recognized by the participants of the study. As a consequence of the study, teachers' perceptions help delineate a proposal which consider current policy constraints and challenges and actions to be taken to establish a more participatory bilingualism model within their context.

Keywords: linguistic policy, Teacher's perception, National Bilingualism Program.

\section{Percepciones de los docentes de lenguas sobre la implementación del Plan Nacional de Bilingüismo: un estudio de caso}

\section{Resumen}

El presente artículo ilustra las conclusiones de un estudio de caso realizado en el municipio de Sogamoso, departamento de Boyacá, Colombia, con el fin de determinar las percepciones de los docentes de idiomas a propósito de la implementación del modelo estatal de bilingüismo en el sistema educativo de la región. El estudio busca, además, contrastar la política adoptada por el Ministerio de Educación Nacional de Colombia (MEN) frente a las expectativas de los docentes de idiomas en relación con la implementación del Programa Nacional de Bilingüismo. Mediante una encuesta y una entrevista grupal y bajo los principios de la investigación cualitativa, las apreciaciones de los docentes revelan una fuerte tensión entre lo propuesto desde el MEN y la realidad que ellos perciben frente a la cuestión. Igualmente, las percepciones de los docentes ayudan a delinear un modelo de bilingüismo que no considera únicamente las restricciones de la política actual sino sus posibles desafíos, para proponer un modelo más participativo desde su concepción hasta su implementación.

Palabras clave: política lingüística, percepción docente, Programa Nacional de Bilingüismo. 


\section{Perceptions des enseignants de langues sur l'implémentation du Plan National du Bilinguisme: une étude de cas}

\section{Résumé}

Cet article illustre les conclusions d'une étude de cas réalisé dans la commune de Sogamoso, au département de Boyacá, en Colombie, ayant le but de déminer les perceptions des enseignants de langues, par rapport à l'implémentation du modelé d'état du bilinguisme, dans le système éducatif de la région. L'étude cherche, en plus, contraster la politique adoptée par le Ministère de l'Education Nationale en Colombie (MEN) face aux expectatives des enseignants de langue par rapport à l'implémentation du Programme National du Bilinguisme. Au moyen d'une enquête et une interview groupale et sous les principes de la recherche qualitative, les appréciations des enseignants, révèlent une forte tension entre ce qui est proposé par le MEN et la réalité qu'ils perçoivent face au sujet. De même, les perceptions des enseignants aident à délimiter un modèle de bilinguisme qui ne considère pas seulement les restrictions de la politique actuelle, mais ses possibles défis, pour proposer un modèle plus participatif dès sa conception jusqu'à son implémentation.

Mots clés: politique linguistique, perception d'enseignant, Programme National de Bilinguisme.

\section{Percepções Dos Professores De Línguas Sobre A Implementação Do Plano Bilingue Nacional: Um Estudo De Caso}

\section{Resumo}

Este artigo ilustra as conclusões de um estudo de caso realizado no município de Sogamoso, departamento de Boyacá, Colômbia, a fim de determinar as percepções de professores de línguas sobre a implementação do modelo estatal de bilinguismo no sistema educacional da região. 0 estudo também busca contrastar a política adotada pelo Ministério da Educação Nacional da Colômbia (MEN) com as expectativas dos professores de línguas em relação à implementação do Programa Nacional Bilíngue. Por meio de uma pesquisa e entrevista em grupo e sob os princípios da pesquisa qualitativa, as avaliações dos professores revelam uma forte tensão entre o que é proposto pelo MEN e a realidade que percebem em relação ao tema. Da mesma forma, as percepções dos professores ajudam a delinear um modelo de bilinguismo que não apenas considera os constrangimentos da política atual, mas também seus possíveis desafios, a fim de propor um modelo mais participativo desde sua concepção até sua implementação.

Palavras-chave: política linguística, percepção de ensino, Programa Nacional de Bilinguismo. 


\section{Introduction}

Our principal concern lays on the fact that the Ministry of Education (MEN) policy has been trying to insert the Bilingualism National Program (BNP) throughout the territory by following a top-down approach, and leaving aside one of the most important components of any educational context: the language teachers (Pinzón, 2014) . Good practice suggests that any education planning should include not only external but also internal participants to make the best decision on designing any policy (Shohamy, 2006; Miranda, 2013). In the case of foreign language education, the most interested parties in developing new projects (besides parents and society in general) should be those who have been trained to become language teachers since they have acquired the knowledge and the experience to deal with language teaching and learning issues within the extremely varied socio-cultural contexts of Colombia (Martínez \& Niño, 2013).

Considering information issued by the Ministry of Education (MEN) ${ }^{1}$, it seems that most of the regions in Colombia have decided to adopt the line of action suggested by the national administration. Briefly speaking, the main endeavors taken so far have to do with two basic requirements: a) evaluating teachers for both language competence and didactic competence and, as a consequence of that evaluation, b) (re)training them to overcome possible drawbacks in their professional performance.

Despite the fact that the NBP has been being implemented for over ten years, expected results and effects are still unfinished. We think that it is time to rethink and redirect the project through a renewed view and an alternate plan that considers the inclusion of language teachers in the design, construction, experimentation and evaluation of a feasible model of bilingualism. A project proposed and executed with teachers' assistance should result in more motivated teachers and a more reachable impact. Thus, in order to proceed, a project that sought the language teachers' perceptions on the implementation of the NBP in the region of Sogamoso was carried out.

The paper firstly presents an overview of the project which includes the methodology, the setting where the study was developed, a brief description of participants, the instruments, and some insights about the work carried out towards the establishment of a bilingual model within the educational system in Colombia. This is followed by a brief discussion on linguistic policy in the country before language teachers' perceptions are presented. Additionally, succinct information about major features of the National Bilin-

1 By the time of this project execution, the MEN presents just a few number of reports about actions and regions where the NBP has been implemented. Further information can be obtained at www.mineducacion.gov.co 
gualism Program is provided so as to get a broader picture of the background where the project was developed. Finally, while discussing the key categories emerged from the study, some recommendations are stated in order to delineate a bilingualism proposal based on language teachers' insights.

\section{Method}

The MEN has reiteratively been applying its own principles and spreading its guidelines throughout the country in the attempt to operationalize the project. The publication of two major documents "Foreign Languages: Curricular Guidelines" ("Idiomas Extranjeros: Lineamientos Curriculares", 1999) and "Basic Standards for Foreign Languages Competencies: English" ("Estándares Básicos de Competencias en Lengua Extranjera: ingles", 2006) are just two documents supporting this policy line. Nevertheless, results in terms of language learning, appear to be a matter of conjecture since the broad goal of the NBP has not been reached despite the fact that more than half of the time projected has passed (Sánchez, 2013; British Council, 2015). The enactment of these documents could be an indication of the fact that the State administration has taken for granted that the decision of designing, applying and evaluating the development of the project solely pertains to the central administration.

On the other hand, the MEN reports that 11.064 language teachers belonging to seventy eight certified secretaries ${ }^{2}$ of education have been evaluated throughout the country (2009). Scores indicates that just $10 \%$ of them have got a level of B2 or above. This result demands an immediate remedy: language teachers need to be retrained in language competence. Thus, it is the MEN together with the British Council that take the responsibility of evaluating and retraining language teachers in a clear application of a top-down strategy.

By contrast, this study sought to explore and hopefully delineate a bottom-up approach (Jiménez, 2015) which considers and includes those who are really going to implement the NBP. Its purpose is to explore the language teachers' feelings and beliefs, and thereafter, what proposals drawn from those perceptions. The research project was designed with the end of illustrating the perceptions of the teachers by means of a questionnaire and a group interview. The study followed the qualitative approach and was intended to be exploratory in its nature as it seeks to describe and understand a social particular case (Dörnyei, 2007).

2 Some Secretaries of Education in Colombia are referred to as 'certificadas' (certified) given a partially administrative autonomy since they do not depend upon Department secretaries but upon the Ministry of Education. 
The study was carried out with 30 in-service language teachers belonging to 11 out of 16 public institutions, rural and urban, that function within the Municipality of Sogamoso in Colombia (Camargo, 2013). All of the participants hold professional degrees of "licenciados" (the Colombian official degree awarded to people trained in both theoretical and practical teaching skills), and some of them have taken postgraduate studies in fields related to language teaching.

A questionnaire and a group interview provided data which were analyzed under the principles of qualitative research methodology. The questionnaire was expected to provide information at a particular level (especially on teachers' background, experience, and information on the NBP) whereas the group interview generated some complementary and more precise insights about their perception on the topic of the study. The questionnaire was piloted to refine some questions and eliminate some others so that the information was as reliable and pertinent as possible (Guerra, 2016). Although the questionnaire was difficult to administer to some participants mainly because of the teachers' excessive work load at their institutions, it was successfully accomplished thanks to an academic event specially devised to the purpose of the study. In fact, the "First Regional Encounter of Language Teachers" was held in the local Secretary of Education and Culture facilities. The meeting pursued two key goals: a) to make the in-service language teachers aware of project, and b) to get them together so as to participate in the group interview.

\section{Research Question and Objectives}

The overall inquiry of the study is focused to find out what the language teachers' perceptions are about the implementation of the National Bilingual Program in the Municipality of Sogamoso ${ }^{3}$, Colombia. The study seeks to:

a. Identify the in-service language teachers' perceptions regarding the implementation of the National Bilingual Program within their work contexts.

b. Evaluate the kind of bilingualism model proposed by the Ministry of Education on the basis of in-service language teachers' perceptions.

\section{Linguistic Policy in Colombia}

A linguistic policy can be defined as a social orientation reflected in linguistic practices, the beliefs and ideology about a given language and the specific efforts made to mod-

3 Sogamoso is a small city located in the middle of the Republic of Colombia, north of South America. For further information see sogamoso-boyaca.gov.co/municipioinforma.shtml?apc $=$ Cexx-1-\&m... 
ify those practices (Spolsky, 2004 as cited by Álvarez, Cárdenas \& González, 2011). The linguistic policy that seeks to foster a bilingual model within the country has historically favored the inclusion of a majority language (English, French, German); this fact is perhaps due to political constrains rather than to population real needs, and has long been implemented by means of the educational system. Spolsky (2005) asserts that a linguistic policy can be easily recognized because it is openly and purposefully stated in official documents as happens within the Colombian case. On the other side, Shohamy (2006) states that educational linguistic policies generally ignore the relationship between the foreign language learning and teaching and the real needs of the object population. That is, they are determined more for political reasons than for academic and pedagogic motives (Galindo \& Moreno, 2014). In the same vein, the author states that these type of policies lack analysis to measure the likeliness of the success, and they are typically imposed by policy-makers with the partnership of powerful organizations, i.e. corporate business.

The current linguistic policy in Colombia has focused towards two different contexts: a) the policy that tries to regulate the relationship between the official language, Spanish, and the minority languages, indigenous and creoles; and b) the policy that tries to establish a bilingual model which includes Spanish and one or more foreign languages (de Mejía 2005, as cited by García \& García, 2012). For the purpose of the study, we focused on the second view since it may be understood that the NBP is the result of a linguistic regulation in Colombia driven by the enactment of the Constitution of 1991 that recognized the linguistic and cultural diversity of the country. Additionally, the National Constitution also opened the possibility to promote the bilingual education especially within indigenous territories, and recently the Law 1381 of 2010 and the decree 1003 of $2012^{4}$ intends to operationalize this possibility.

It is not imprecise to say that before the issue of Law 115, known as "General Law of Education" (1994), some transitory regulations were promulgated that cannot be taken as parts of a real policy ${ }^{5}$. In the past, for instance, the teaching of English and French as foreign languages in 1824 in a secondary school in Bogotá as well as the decision of teaching French 10 and 11 grade students and English for 6 and 7 grades in 1979 evidence the inexistence of a real linguistic policy (de Mejía \& Montes 2011, as cited by García \&

4 For further information refer to http://www.vicepresidencia.gov.co/Programas/Documents/121207-LEY-DE-LENGUAS.pdf

5 There is a range of definitions even contradictory from one another. For the sake of clarification, we will adopt the definitions proposed by Studer, Kreiselmaier, and Flubacher (2008): "Language policy..., refers to the outcome of planning, the act of reconciliation or accommodation, which may take the form of a resolution, a draft paper, a motion, or, in less political terms, a simple understanding between participants".

For further illustration see http://www.academia.edu/1406650/Language_Policy-planning_in_a_Multilingual_European_Context 
García, 2012). Likewise, in 1982 the MEN together with the British Council and the Colombo-American Institute designed "The English Syllabus" that sought to introduce the foreign language within the second school curriculum. Later on, another project known as COFE (Colombian Framework for English) was accomplished with the partnership of the United Kingdom. This time the project focused on retraining in-service language teachers of both private and public universities and on revising the teacher preparation programs. To some extent, this project fostered research agendas and syllabuses revision within participating universities (Frodden \& Correa, 2000 as cited by Usma, 2009).

More recently, the MEN proposed the "Curricular Guidelines for Foreign Languages" (Lineamientos Curriculares Lenguas Extranjeras, 1999), a document that illustrates, from a theoretical perspective, the teaching and learning process of foreign languages. Also, it defines key concepts to revise curricular plans at institutions as well as considerations on potential application of new technology to language teaching. More than five years later, a new official document, "Basic standards for Foreign Languages Competences: English" was enacted with the end of operationalizing foreign language learning under the premise of "making citizens capable of communicating in English in such a way that they can insert the country into the processes of universal communication, into the global economy and into the cultural openness with internationally comparable standards" (MEN, 2006, p. 6). The document describes in some detail the minimal degree of FL competence, worded in terms of short descriptions, a students must attain to move from one level to next one. The road was finally paved to launch one of the most ambitious projects to the teaching and learning of English in the Colombian educational system: the National Bilingualism Program (2004).

\section{Teachers' Perceptions}

From the psychology viewpoint, the concept of perception has been defined as the "cognitive process of the conscience that consists of recognition, interpretation and meaning for the elaboration of judgments concerning the sensations obtained from the physical and social environment" (Vargas, 1994, p. 48). In a more anthropologic vision the author emphasizes that perception is an elaboration process of structures which is carried out by means of the subject's socialization within the group s/he belongs to. This process involves a symbolic construction of ideological and cultural models.

To talk about perceptions implies approaching the individual from her/his deeper nature; that is to say, it suggests trying to outline the reason of a behavior, of a belief, of an attitude, or of an action. These psychological events take place due to a formal or informal learning that shapes people's reactions. It is necessary to have perceived to know, and to 
have known to establish attitudes and beliefs facing a vast array of realities within which a human being will be immersed along his/her entire life.

Beliefs are an essential component of people's behavior and attitudes which influence how an individual makes decisions within a certain event or in a particular situation. Talking about the specific case of the language teachers, their pedagogic decisions are intimately related to their previous learning experiences and professional performance. Hargreaves and Fullan (1992) state that a belief is what a teacher thinks, a teacher believes, and what s/he does within a classroom, and that is what finally shapes the kind of learning a pupil is going to acquire. In short, what a person thinks is true or real, it is considered as to be a belief. Nevertheless, a belief refers to suppositions, commitments and ideologies whereas knowledge has to do with actual propositions and understanding (Calderhead, 1996).

In the same vein, Kindsvatter, Wilen, and Ishler (1998) hold that the teachers' belief system is constructed across time and both a subjective and objective dimension take part in the process. According to these authors, the system is rooted in diverse sources:

1. Teacher's own experience as language's learners.

2. Their experience on their successful performances.

3. Pre-established practices in the institutions.

4. Personal factors: preferences for certain didactic practices which adjust to their personality.

5. Practice derived from theoretical foundation: language nature and principles of language learning and teaching.

\section{The National Bilingualism Program}

Seeking to enhance the quality of the Colombian educational system in order to meet the international requirements, the MEN designed and is implementing a challenging project that intends to improve students skills in English as a foreign language. The project states, as its most demanding goal, that by the end of the 2019, we might have a bilingual (Spanish-English) society. This purpose is detailed according to the Common European Framework standards from which the MEN has adapted its own standards: 
Table 1. CEF \& MEN Standards

\begin{tabular}{|c|c|c|c|c|}
\hline $\begin{array}{c}\text { CEF } \\
\text { level }\end{array}$ & MEN level & School Grade & $\begin{array}{c}\text { Age } \\
\text { (Approx.) }\end{array}$ & Performance Level \\
\hline A1 & A1 & $1-3$ & $6-8$ & Beginner \\
\hline A2 & A2.1 & $4-5$ & $9-11$ & Basic 1 \\
\cline { 2 - 5 } & A2.2 & $6-7$ & $12-13$ & Basic 2 \\
\hline B1 & B1.1 & $8-9$ & $14-15$ & Pre-intermediate 1 \\
\hline & B1.2 & $10-11$ & $16-17$ & Pre-intermediate 2 \\
\hline B2 & & $\begin{array}{c}\text { Tertiary educa- } \\
\text { tion }\end{array}$ & $18-$ on & Intermediate \\
\hline
\end{tabular}

Furthermore, with the introduction of an official document that delineates the basic standards of the foreign language competences (2006), the MEN presents the route for the institutions, students and teachers to guide the instructional process to attain the goal. This document contains a list of basic standards for all grades of primary and secondary school worded in terms of descriptions of the expected outcomes a student should reach and show. It is worth noting that standards referred to are adapted from the European Common Framework project (Council of Europe, 2001) that barely recognizes the idiosyncratic features of local culture, learning and teaching conditions and sociolinguistic environment of the broad linguistic varieties of Colombia.

Nonetheless, the NBP has defined a series of strategies to make this key purpose possible: a) the definition of standards in English competence; b) the evaluation of language competence in students, in-service teachers and pre-service language teachers; c) the offer of improving programs on language competence and language teaching skills, and d) the incorporation of new technology into the English teaching/ learning.

\section{Findings and Discussion}

The instruments were separately analyzed so as to find comparable parameters with the purpose of assigning reliability to the analysis. Once this was completed, a joint review was accomplished to establish diverse and/or complementary results between both instruments.

\section{Questionnaire Analysis}

In the first instance, it was believed that the teachers of the rural institutions and those of the urban institutions might reveal likely differences so previous analysis was done 
to establish some valuable data generated by this socio-cultural condition. Nevertheless, the major discrepancy has to do with the lack of information about the activities within the framework of the NBP.

Regarding the possibility of implementation of the NBP in the Colombian context the participants unanimously agree that this program may be beneficial and they provide a number of reasons including globalization participation, international communication access, academic improvement, access to knowledge and mainly positive regarding the probability of permanent professional development. In sum, the participants believe that the NBP would offer Sogamoso's students more benefits than harm.

Regarding the individual participation in the implementation of the NBP, $38 \%$ of the questioned expresses to have taken some part in activities proposed by the program, whereas $64 \%$ argue that they have not participated in any activity programed by the NBP. The activities the teachers have been part of are summarized as follows: foreign language diagnosis 64\%; programs of language improvement 52\%; English didactics retraining programs 28\%; and Institutional Educational Project (PEI, for Proyecto Educativo Institucional) adjustment $8 \%$.

Participants were also asked about what they perceive regarding the implementation of the NBP in Sogamoso. Key respondents' insights may be summarized into three major categories: a) issues related to Secretary of Education (SEC) policy; b) issues related to professional development (mainly referred to as language and didactics retraining) and c) concerns regarding the PEI. The table 2 groups the most recurring opinions.

Table 2. Insights from questionnaire

\begin{tabular}{|l|l|l|}
\hline \multirow{4}{*}{ SEC policy } & 1 & Lack of projects \\
\cline { 2 - 3 } & 2 & Lack of acknowledgment of the local context \\
\cline { 2 - 3 } & 3 & Poor resources management \\
\cline { 2 - 3 } & 4 & Poor coverage and opportunity for teachers participation \\
\cline { 2 - 3 } & 5 & Need for primary teachers training \\
\cline { 2 - 3 } & 6 & Need for postgraduate education \\
\hline \multirow{4}{*}{ Training } & 1 & Poor or unavailable training in NBP \\
\cline { 2 - 3 } & 2 & No training in FL Competences \\
\cline { 2 - 3 } & 3 & Unavailable training in FL Didactics \\
\cline { 2 - 3 } & 4 & No training in new technologies applied to FL teaching/learning \\
\cline { 2 - 3 } & 5 & Need for research training \\
\hline
\end{tabular}




\begin{tabular}{|l|l|l|}
\hline \multirow{4}{*}{ PEI } & 1 & Need for curricular design (a cross-curricular syllabus) \\
\cline { 2 - 3 } & 2 & Establishment of resource centers \\
\cline { 2 - 3 } & 3 & Need for evaluation development \\
\cline { 2 - 3 } & 4 & Need for specialized classrooms \\
\cline { 2 - 3 } & 5 & Class hours number / number of students per class adjustment \\
\hline
\end{tabular}

When asked about their perceptions on the language standards adopted by the MEN the participants presented a wide range of opposing opinions going from "subjective, abstract, hard to attain, a utopia" to "necessary, important as reference, well done". In-service teachers also assure that in order for their students to attain minimal standards it is absolutely necessary to implement curricular conditions as well as the timely and relevant language teachers professional retraining. In general terms, the adoption of standards can be considered to be an ideal state which orientates the route to go for developing the bilingualism project. Inevitably all entities and people concerned with the project need the required commitment in terms of financial investment and willingness to take the challenge that implies a change of this significance.

When questioned on the Secretary of Education's interest and participation in the national project, teachers think that it is actually very limited. One of the factors of major incidence seems to be the lack of coherent, pertinent and stable policy actions supporting the NBP. In fact, they say that there have been some administrative interruptions that have affected the implementation of the NBP e.g. the frequent change of administrators (secretaries of education, assistants) brings about breaks in the process. Undoubtedly, serious concern should be devoted to the design of a bilingualism-oriented educational policy; however, by the time of this study development, any official regulation in this sense seems to be part of the local administration agenda.

Additionally, some of the few activities carried out in Sogamoso have been required by the MEN which the local SEC has closely followed. For instance, the immersion programs have caused a feeling of frustration for in-service teachers since the selection procedures were designed for teachers with high language standards, leaving aside teachers who actually needed language improvement; in addition, no follow-up activities were planned so as to assess the immersion activity purpose.

Finally, participants were asked to provide suggestions which might be helpful when implementing a bilingualism plan within their municipality. The Table 3 groups major insights on this issue. 
Table 3. Language teachers' suggestions to implement the NBP

\begin{tabular}{|l|l|}
\hline \multirow{5}{*}{ SEC } & To Foster financial support for didactic resource center \\
\cline { 2 - 3 } & To design and carry out bilingualism-focused projects. \\
\cline { 2 - 3 } & Timely communication among language in-service teachers \\
\cline { 2 - 3 } & $\begin{array}{l}\text { Impartiality and full coverage for the official summons. } \\
\text { Establishment of agreements with private and public entities. }\end{array}$ \\
\cline { 2 - 3 } & To engage primary in-service teachers \\
\cline { 2 - 3 } & To set working agendas / working teams. \\
\cline { 2 - 3 } & Steady and systematic follow-up \\
\cline { 2 - 3 } & To structure bilingual projects into other projects \\
\hline \multirow{5}{*}{ CAP } & Professional development for pre-school and primary teachers. \\
\cline { 2 - 3 } & To foster teacher exchange. \\
\cline { 2 - 3 } & To train language teachers in ICTs with emphasis on FL issues. \\
\cline { 2 - 3 } & To support in-service language teachers in graduate studies. \\
\hline \multirow{5}{*}{ PEI } & To revise and adjust study plans. \\
\cline { 2 - 3 } & To design FL syllabus. \\
\cline { 2 - 3 } & To design learning materials. \\
\cline { 2 - 3 } & To set evaluation and testing policies (process and result). \\
\hline
\end{tabular}

\section{Interview Analysis}

In order to perform the focus group interview, the participants were randomly assigned into three different groups. They were informed about the procedure of the activity and of the reasons for which this interview was going to be videotaped. The main reason was to try to gather information as faithfully as possible otherwise would be virtually impossible when dealing with a group interview. Three groups of teachers were established to make the interview with an approximate number of 8 participants per table; a tutor, who had been previously trained, was assigned to lead the session.

Once the video transcription was done, the three groups were analyzed separately to get independent data for comparison. It was expected that this procedure would add validity to the analysis. Upon crossing information five provisional categories emerged: Training, NBP (National Bilingualism Program), SEC (Secretary of Education), Teachers and PEI (Institution Educational Project). After analytical readings these five categories were reduce to three since some embraced others; the major classifications were designed as a) Policy, b) Teachers, c) Curriculum development. Each category represents most outstanding and frequent participants' concepts and these insights were told either as complaints or as suggestions. Table 4 illustrates these impressions. 
Table 4. Perceptions based on the interview

\begin{tabular}{|c|c|}
\hline \multirow{15}{*}{ POLICY } & Lack of projects on bilingualism \\
\hline & Lack of bilingualism-oriented policies \\
\hline & Lack of systematic immersion follow-up activities. \\
\hline & There is no a bilingualism project. \\
\hline & Lack of local policies. \\
\hline & Weak school administration support. \\
\hline & Low salaries \\
\hline & $\begin{array}{l}\text { Immersion-selecting process does not take academic level into account. (tests do } \\
\text { not actually measure teachers' professional performance) }\end{array}$ \\
\hline & $\begin{array}{l}\text { Number of Language teachers attending immersion programs is perceived as too } \\
\text { low. }\end{array}$ \\
\hline & Immersion program participants' evaluation should be objective \\
\hline & $\begin{array}{l}\text { SEC policy (in terms of assigning immersion participants responsibility for imple- } \\
\text { menting the NBP) }\end{array}$ \\
\hline & To include follow-up actions to short-term and long-term projects. \\
\hline & Financial support for projects. \\
\hline & To implement a specialized room (center) at SEC. \\
\hline & $\begin{array}{l}\text { The NBP did not consider language teachers as potential assistants for its design and } \\
\text { implementation. }\end{array}$ \\
\hline \multirow{12}{*}{ TEACHERS } & No professional training for primary teachers. \\
\hline & Poor, if any, access to ICTs. \\
\hline & Low teachers' interest and motivation. \\
\hline & Low students' motivation as a result of low teachers' interest. \\
\hline & Little opportunities for immersion practice. \\
\hline & Encourage local immersions to improve coverage and reduce cost. \\
\hline & Pertinent training for language teachers while working in extra-curricular activities. \\
\hline & Low salaries for education professional workers. \\
\hline & Training in ICTs related to EFL teaching and learning process. \\
\hline & To establish inter-institution working teams. \\
\hline & Teachers' full commitment to participate in projects to implement the NBP. \\
\hline & Didactic resources to support teaching. \\
\hline
\end{tabular}




\begin{tabular}{|l|l|}
\hline \multirow{y}{*}{ CURRICULUM } & To revise number of class hours. \\
\cline { 2 - 3 } DEVLOPMENT & To design genuine (local-based) syllabus. ( Foreign models just as reference) \\
\cline { 2 - 3 } & To have in mind distinction between foreign and second language. \\
\cline { 2 - 3 } & To consider number of learner per class. \\
\cline { 2 - 3 } & To standardize course content. \\
\cline { 2 - 3 } & To implement English for levels (according to performance instead of scholar years) \\
\cline { 2 - 3 } & To include virtual support for teaching and learning. \\
\cline { 2 - 3 } & $\begin{array}{l}\text { The design of K-11 language content with direct participation of language teachers } \\
\text { and based on adopted standards. }\end{array}$ \\
\cline { 2 - 3 } & $\begin{array}{l}\text { To Foster bilingualism without sacrificing the mother tongue; to consider including } \\
\text { other languages. }\end{array}$ \\
\cline { 2 - 3 } & $\begin{array}{l}\text { To keep in mind learners with special learning needs while designing the curricu- } \\
\text { lum. }\end{array}$ \\
\cline { 2 - 3 } & To sensitize parents to become extracurricular supporters to education projects. \\
\hline & $\begin{array}{l}\text { To inform students about the teachers' immersion experiences (innovative materi- } \\
\text { als and teaching strategies) }\end{array}$ \\
\hline
\end{tabular}

\section{Joint Analysis and Discussion}

Once findings from the instruments were obtained and data analyzed, a triangulation procedure was applied in order to establish information that might complete each other. In general terms, the obtained information shows clearly a reiteration of the language teachers' perceptions in relation to the NBP being implemented in the Municipality. Three categories emerge as representative groups of information where most of the teachers' impressions can be allocated. These categories are:

The linguistic planning, as taken in this study, refers to the set of laws, norms, and regulations that make possible the implementation of a foreign language within the preschool, primary and secondary curricula of the institutions participating in this project. In this vein, it is undeniable that the Municipality of Sogamoso lacks policies directly related to the establishment of the NBP according to the participants' responses. In fact, the Secretary of Education has just followed general guidelines set by the Ministry of Education particularly addressed to the immersion-like training.

It is worth saying here that the educational and linguistic policy of the MEN goes beyond the scope of this study therefore it is not an object of review and it will be taken tan- 
gentially when needed. Considering the lack of clear and pertinent guidelines, the teachers suggest that it is the Secretary of Education, the entity that must lead the process of implementation of the NBP, and accordingly, it is necessary the language teachers' incorporation into the design of policies and strategies that are going to delineate the process. The policies will have to consider as a starting point some concepts that we think are fundamental for this purpose, for instance: the recognition of the idiosyncrasy of the local, both rural and urban context; the analysis of the type of bilingualism that is to be attained in the municipality; the necessary distinction between foreign and second language; the relationship among the national policies and their effects on the designing of regional policies; the teachers' experience in bilingual education; and the conceptual support for a systematic and permanent evaluation of every element of the process.

The second category, teachers, encompasses the very nature of the study since it is the teachers themselves who acknowledge their role as active and proactive members of the language teaching community. First of all, the participants acknowledge low levels of motivation that can be related to the poor participation of the SEC in the project of bilingualism. Also, they accept that this low motivation might be being transmitted, consciously or unconsciously, to his students with the potential risk of planting in them emotional demotivation to even accept the possibility of learning a foreign language. In this sense, teachers recognize something they referred to as a sort of a laisser faire, laisser passer attitude that in the field of education would be seen as unprofessional. Nevertheless, most of the participants also express their enthusiasm and willingness to undertake projects that recognize the socio-cultural and socio-economic situation of each one of the institutions where they work. What is more, they are demanding to be recognized as experienced language teachers and as such a potential and essential factor to address the projects needed to establish the bilingualism or bilingual education in their regions.

In addition, the professional development is a constant concern of teachers. They request training mainly in the development of communicative competence in FL and in teaching skills of FL. Furthermore, since the perception that a project of bilingualism must start from the beginning, that is, from the early age of pre-school education, training for teachers who work in the pre-school and in primary levels basic communication and didactic skills development becomes an obligatory issue for the administration and for the educational community. It should be noted however, that the training for this particular group of teachers must be different from the current immersion training proposed and de- 
veloped by the national administration, since most of primary level teachers lack sufficient linguistic foundations to attend successfully an exercise of immersion ${ }^{6}$.

Most of the participants agree that immersion could be a professionally enriching experience; however, a feeling of frustration comes up due to the lack of any follow-up activities supported by sustainable and measurable projects. They also draw attention for greater coverage and opportunity for all in-service teachers and request a review of the selecting criteria for this practice. For this reason, participants propose a teacher-oriented local immersion which should be conducted by a group of experienced trainers in both communicative competence and didactics of the foreign language. In addition, we believe that academic training in bilingual education is paramount because what the MEN pursues through the NBP is the learners' improvement of the foreign language, and this would not be possible if English is seen as one more subject of the curriculum (as it has been so far) and what is even worse, assigning direct responsibility for learning to the teachers that teach this subject.

On the other hand, unanimously and reiteratively, participants demand systematic and up-to-date training in Information and Communication Technologies (ICT) particularly oriented to FL teaching and learning. This type of training involves the adoption of necessary technical support to learning as well as to follow-up and evaluation issues not only for the teachers' training but also for the students' learning and practice processes. To this end, the teachers suggest the use of their own time to overcome this training successfully. Furthermore, the National Government runs a macro-project to expand the use of new technologies all over the country; this fact would guarantee to some extent, that a proposal like the above one would get a positive response.

Finally, it is important to state that curriculum development is grounded in the social and political conceptions affecting the educational system of a given region; thus, it is worth considering the particular education purposes that encompasses the curriculum, e.g. syllabus design, teaching method, material and teaching resources availability and the definition of an evaluation framework which permanently orientates both process and outcomes (Richards, Platt \& Platt, 1999).

Before beginning a curriculum review, it is necessary to take into account social and cultural idiosyncrasy of the region so as to design a curriculum that meets the students' needs and region requirements as well as to consider teachers' availability and adminis-

6 The majority of primary and pre-school teachers have no FL training. In most institutions they are teaching all school subjects including English. 
tration commitment. What is sought it is to design a curriculum that can be applicable and measurable within short and long term. To this purpose, it is necessary to develop key components such as method, methodology, activities and materials. Likewise, the decision about what kind of bilingualism or bilingual education really fits the educational setting of the municipality is paramount to this end ${ }^{7}$. Moreover, another important aspect mentioned by the participants, is the design of a curriculum that considers all sort of potential target population, especially those students with learning disabilities and on the other side, a design that takes parents as an important extracurricular support to foreign language learning.

The participants suggest, on the other hand, the review of the standards adopted by the MEN for the implementation of the BNP that they consider to be far from the academic and sociocultural reality of the region. It is important to remember that the MEN resolved to adapt standards from the international standards of the Common European Framework project, a controversial issue that has generated a wide-ranging discussion in our country. In our opinion, a reasoned discussion about standards should take place once the type of bilingualism to be implemented is defined since what is sought is a coherent relationship between what is proposed and what can be attained.

In theory, the design of a curriculum must envisage aspects like number of class hours, number of students per class, sequence of content, promotion criteria, evaluation and assessment parameters, design and implementation of learning materials, among others. A question arises about whether the regional administration and the institutions administrations are prepared to approach a review and a possible adjustment of this magnitude. In our view of the situation, we think that it is very premature to wait a positive response from the present exploratory study; rather, we believe that a minor-scale curriculum development must be designed and applied to a single class of a single institution for a reasonable time. This pilot study should generate a more trustful design to be expanded all over the institutions of the region.

It seems that the language teachers claim for the establishment of a standardized curriculum whose bases come from the teachers' experience and knowledge and the active participation of the Secretary of Education. This kind of curriculum would guide the academic particular determinations of the institutions and would establish the necessary conditions to reach a level of FL consistent with the needs of the region and the requirements of the country. In addition, they propose a design that considers cross-curriculum

7 National authorities encourages innovative local proposal as long as Nation general guidelines are kept. 
projects, in other words, to involve content subjects and English language learning. This is another decision to be made after the type of bilingualism or of bilingual education is defined. Finally, the design should also include the promotion of intra-institutional and inter-institutional events as a way of keeping the students' motivation to learning latent while raising the teachers' engagement. As a matter of fact, some events like song festivals, English Olympics, English Day which are currently being developed in some institutions of the region, even without the local administration support, should be kept and expanded.

\section{Conclusion}

The data-collecting instruments sufficed to gather relevant information to have insights related to the current implementation of the NBP in state schools in Sogamoso. Language teachers as main actors of the project were able to reflect on their own professional performance and on the organization of the educational system. The three main categories discussed, linguistic planning, teachers, and curriculum development, offer not only an enhanced depiction of teachers experience as dependents of the Secretariat and school organization but also opinions regarding innovation, including a bilingualism model conceived, implemented, and evaluated by the language teachers, supported and guided by official entities.

Sogamoso's language teachers are fully aware that they have been set apart from the conception and designing of the NBP, and they have also realized that the local educational authorities lacks its own initiatives to undergo innovative proposal in terms of spreading a bilingualism model within the region. This fact has significantly demotivated teachers to the extent they exhibit a high degree of reluctance to even attend Secretary of Education calls to develop any kind of proposals. For more than three years, the authors of this paper have themselves endured the local government extreme indifference that would explain that they are interested just in receiving and following instructions from the national authority.

The categories discussed prove the teachers' professional capacity in terms of proposing clear educational policies, determining academic needs and designing local-based curriculum. In fact, a determined and disinterested communication between the educational community and the local administration will provide the balance needed to attain an educational organization so as to the establishment of the NBP in the Municipality. Furthermore, the language teachers of the Municipality exhibit an authentic interest in the implementation of the PNB within their institutions as long as there exists a project led by the municipal administration in which the teachers' voices regain credibility and acceptance at the time of making decisions about what is more suitable for the their own learning communities. 


\section{References}

Álvarez, J., Cárdenas, M. \& González, A. (2011). Cobertura vs. continuidad: dos retos para el desarrollo profesional para los docentes de inglés en el Marca de Colombia Bilingüe. En Fundamentos para el Desarrollo Profesional de los Profesores de Inglés (pp. 119-154). Pasto, Colombia: Graficolor.

British Council (2015). English in Colombia: An Examination of Policy, Perceptions and Influencing Factors. Retrieved from https://ei.britishcouncil.org/sites/default/files/latinamerica-research/English\%20in\%20Colombia.pdf

Calderhead, J. (1996). Teachers: Beliefs and knowledge. In D. Berliner, \& R. Calfee (Eds.), Handbook of Library Reference. Educational Psychology (pp. 709-725). NewYork: Macmillan.

Camargo, D. (2013). Gender Positioning in the Development of EFL activities. Cuadernos de Lingüística Hispánica, (22), 147-166.

Council of Europe (2001). Common European Framework of Reference for Languages. Cambridge, UK: Cambridge University Press.

Dörnyei, Z. (2007) Research Methods in Applied Linguistics. New York: Oxford University Press.

Galindo, A., \& Moreno, L. (2014). Formación bilingüe en licenciatura de Lenguas Modernas y comprensión lectora argumentativa. Cuadernos de Lingüística Hispánica, (23), 171-190.

García L. J. \& García L. D. (2012) Políticas lingüísticas en Colombia: tensiones entre políticas para lenguas mayoritarias y lenguas minoritarias. Boletín de Filología, 47(2), 47-70.

Guerra, J. (2016). Peer support in small group EFL writing tasks. Cuadernos de Lingüística Hispánica, (28), 207-232.

Hargreaves, A. \& Fullan, M. G. (1992). Understanding Teacher Development. New York: Teachers College Press.

Jiménez, P. (2015). Exploring students' reactions when working teaching materials designed on their own interests. Cuadernos de Lingüística Hispánica, (25), 201-222.

Kindsvatter, R., Wilen, W. \& Ishler, M. (1998). Dynamics of Effective Teaching. New York: Longman.

Martínez, A., \& Niño, P. (2013). Implementing tasks that stimulate critical thinking in EFL classrooms. Cuadernos de Lingüística Hispánica, (21), 143-158.

Ministerio de Educación Nacional (1994). Ley General de Educación. Bogotá: Imprenta Nacional.

Ministerio de Educación Nacional (1999). Idiomas Extranjeros: Lineamientos Curriculares. Santafé de Bogotá: Enlace. 
Ministerio de Educación Nacional (2006). Estándares básicos de competencias en lenguas extranjeras: inglés. Bogotá: Imprenta Nacional.

Ministerio de Educación Nacional (2009). Organización del Sistema Educativo. Guía 33. Recuperado de www.mineducacion.gov.co

Miranda, I. R. (2013). Percepciones de los docentes de idiomas sobre la implementación del Plan Nacional de Bilingüismo en el Municipio de Sogamoso, Colombia. (Informe de investigación no publicado). Universidad Nacional de Educación a Distancia.

Pinzón, R. (2014). English teaching through project based learning method, in rural area. Cuadernos de Lingüística Hispánica, (23), 151-170.

Richards, J., Platt, J. \& Platt, H. (1999) Dictionary of Language Teaching and Applied Linguisitics. Malaysia: Longman Group UK.

Sánchez, A. (2013). Bilingüismo en Colombia. Centro de Estudios Económicos Regionales. Documentos de trabajo sobre economía Regional. Cartagena: Banco de la República. Retrieved from http://www.banrep.gov.co/docum/Lectura_finanzas/pdf/dtser_191.pdf

Shohamy, E. (2006). Language Policy: Hidden Agendas and New Approaches. New York: Routledge.

Spolsky, B. (2005). Language Policy. In J. Cohen, K. McAlister, J. Rolstad \& J. MacSwan (ed.), In Proceedings of the $4^{\text {th }}$ International Symposium on Bilingualism (pp. 2152-2164). Sommerville, MA: Cascadilla Press.

Studer, P., Kreiselmaier, F., Flubacher, M. (2008) Language Policy-Planning in a Multilingual European Context. Bern, die Schweiz: Universität Bern Institut für Sprachwissenschaft.

Usma, J. (2009) Education and Language Policy in Colombia: Exploring Processes of Inclusion, Exclusion, and Stratification in Times of Global Reform. Profile, 11, 123-141.

Vargas, L. M. (1994). Sobre el concepto de percepción. Alteridades, 4(8), 47-53. 